\title{
JEUG EN KERK
}

\author{
DR. A. BREEDT
}

\section{INLEIDING}

Met die onderhawige artikel word beoog om die lig te laat val op die jeugdiges in Suid-Afrika se mening aangaande sekere kerklike aangeleenthede. Die gegewens wat hiermee verstrek word, is verkry na 'n landurige jeugondersoek wat deur die Departement Sosiologie, in opdrag van die Nasionale Jeugraad van die F.A.K., onderneem is.

Die jeugondersoek het by wyse van vraelyste nagenoeg 6,000 jeugdiges tussen die ouderdomme 16 en 25 jaar in die ondersoek betrek. Hierdie vraelyste is in persoonlike onderhoude met die jongmense voltooi en later in samewerking met die Nasionale Buro vir Opvoedkundige en Maatskaplike Navorsing en die W.N.N.R. verwerk. Die ondersoek het oor in tydperk van drie jaar gestrek en is in Desember 1966 afgehandel.

Aanvanklik is die volgende vier afsonderlike ondersoeke geloods :

(a) Die kerklike- en godsdienstige lewe van die jeug.

(b) Die beroeps- en ekonomiese lewe van die jeug.

(c) Die vryetydsbesteding van die jeug.

(d) Die volks- en kulturele lewe van die jeug.

Later is 'n vyfde opname oor bestaande jeugorganisasies bygebring in ' $n$ poging om vas te stel in watter mate hierdie organisasies die jongmense bereik en hoedanig die organisasies hulle doelstellings verwesenlik.

Vanweë gebrek aan die nodige tyd, is slegs Afrikaanse jeugorganisasies in laasgemelde opname genader.

Met betrekking tot die aspekte wat vervolgens behandel sal word, is ' $n$ steekproef van 1,497 jeugdiges betrek. Hierdie steekproef is wat geslag, verblyfplek, ouderdom, huwelikstaat, kerkverband, onderwyskwalifikasies, beroep en huistaal betref, verteenwoordigend van die totale aantal jeugdiges tussen 16 en 25 jaar in die land. Alvorens oorgegaan word tot die bespreking van enkele tendense wat uit die ondersoek geblyk het, dien die volgende beklemtoon te word: 
(a) In die eerste plek was hierdie 'n sosiologiese verkenning van ' $n$ breë terrein. Daar word dus nie aanspraak gemaak op ' $n$ deeglik deurdagte en diepsinnige kennisname van al die teologiese implikasies wat met die onderhawige aspekte gepaard gaan nie. Die bedoeling van die skrywer is ook geensins om in 'n teologiese diskussie betrokke te raak nie.

(b) In aansluiting by bogemelde kan genoem word dat, ten opsigte van die drie aspekte wat bespreek gaan word, die skrywer persoonlike onderhoude met ondermeer proff. B. J. Engelbrecht, A. D. Pont, J. I. de Wet, dr. J. P. Oberholzer en ds. P. M. Smith gevoer het. Hierdie persone was behulpsaam met die formulering van die vrae, asook met sekere gedeeltes van die interpretasie daarvan.

(c) Voorts is die lewens- en wêreldbeskouing van die Protestants - Afrikaner - gelowige, soos dit tot uiting kom in die Calvinisme, as die uitgangspunt en maatstaf vir beoordeling by die skrywe hiervan gebruik. Prakties gesproke kom dit, byvoorbeeld, daarop neer dat die jongmense se opvatting van die verhouding tussen die kerk en die staat, beoordeel sal word aan die hand van die mate waarin hulle die Calvinistiese beskouing in dié verband onderskraag of verwerp.

Met bogemelde gedagtes as agtergrond, kan agtereenvolgens oorgegaan word tot die bespreking van die jeugdiges se siening van die verhouding tussen die kerk en die staat, hulle opvatting van die Bybel en hulle beskouing aangaande die prediking in die kerk.

\section{DIE JEUGDIGES SE SIENING VAN DIE VERHOUDING TUSSEN DIE KERK EN DIE STAAT}

Die Calvinisme handhaaf die standpunt dat die onderskeie menslike verbande of lewenskringe (kerk, staat, volk, gesin, ensovoorts) elk ' $n$ eie unieke gesagstruktuur, ' $n$ eie eenheidstruktuur, ' $n$ eie struktuurprinsipe, ' $n$ eie sin, doel, taak en roeping het wat in beginsel van God ontvang is. Geeneen van hierdie menslike verbande mag die ander oorheers, probeer vervang of vernietig nie. Elkeen van hierdie lewensverbande is selfstandig en kan alleen as sodanig sy van God gegewe roeping vervul en wel volgens sy van God gegewe sin en eie aard. Verder bestaan hierdie lewensverbande nie geisoleer van mekaar nie, maar is hulle onderling vervleg, op mekaar aangewys en vul hulle mekaar op ' $n$ harmoniese wyse aan. Vrye wisselwerking tussen die onderskeie lewensverbande is derhalwe nodig sodat elkeen afsonderlik en almal gesamentlik aan hul doel kan beantwoord wat uiteindelik gelyk staan met die eer en verheerliking van God (vgl. 15, p. 13). 
Uit bogemelde volg nou dat die kerk en die staat elkeen sy eie struktuur, wese, taak en roeping het om te vervul. Die kerk is nie staat nie, die staat is ook nie kerk nie. Die een kan nie die funksie van die ander oorneem nie. Ofskoon daar egter 'n skerp onderskeid tussen kerk en staat bestaan, mag hulle nie van mekaar geskei word nie vanweë die feit dat hulle op verskillende wyses vervleg is. So, byvoorbeeld, word die kerk deur die staat erken, beskerm en beveilig kragtens die staat se funksie van regshandhawing en regsvorming. Die staat verwag weer van die kerk gehoorsaamheid aan die owerheid. Die Nederlanđse Geloofsbelydenis stel dit duidelik dat elkeen verplig is om hom „,aan die owerheid te onderwerp, belastings te betaal, aan hulle eer en eerbied te betoon en hulle gehoorsaam te wees in alles wat nie stry met die Woord van God nie" (Artikel 36). Die kerk kan die staat vra om wetgewing uit te vaardig wat kerklike bélange raak, byvoorbeeld, teen Sabbatsontheiliging, teen loterye, teen gemengde huwelike ensomeer. Andersyds vra die staat die kerk om sekere godsdienstige handelinge vir hom te verrig, byvoorbeeld, biddae in krisistye, die opening van die Volksraad met gebed ensovoorts. Daarom word gepraat van kerk en staat as afsonderlike lewenskringe wat wel met mekaar in verband staan, maar tog ook afsonderlik en naas mekaar bestaan, elkeen volgens sy eie roeping gebonde, maar vry en selfstandig teenoor die ander. In hierdie verband laat Hanekom hom soos volg uit:" "Dieselfde groep mense kan burgers van die Staat en lidmate vah die Kerk wees, sonder dat die Kerk en Staat om daardie rede sal saamsmelt om geboorte te gee aan 'n Staatskerk of 'n Kerkstaat. Die lewe soek sy eie vryheid en gehoorsaam daarmee die diepste behoefte wat die wyse Skepper daarin gelê het deur elke lewenskring aan sy eie wette te bind, sonder onderworpenheid aan dié van ander terreine. So sal die Staat wat Christelik wil optree, nie sy Christelikheid openbaar deur hom aan die Kerk te onderwerp nie, maar deur sy gewilligheid om voor God te buig en die leiding van Sy Woord te volg" (8, p. 9; vgl. ook 7, pp. 154 $155 ; 15$, p. 228 , pp. $234-235$; 21, pp. $42-44 ; 22$, pp. $55-62$ ).

Die wedersydse beinvloeding, dog afsonderlike taakvervulling, van kerk en staat blyk derhalwe duidelik. Elkeen het op sy eie bepaalde terrein 'n taak en funksie maar die een mag nie van die ander onderskei of aan die ander onderwerp word nie. Die kerk verkondig die Woord van God en is nie mederegeerder van die land nie. Die verkondiging van die Woord geld vir alle mense, op watter lewensterreine hulle ookal beweeg. Treurnicht konkludeer: .,So moet die kerk hom ook rig tot die owerheid om hom daaraan te herinner dat hy 'n dienaar van God is wat kwaaddoeners moet straf, regmatige vryhede moet beskerm en in ge- 
ordende samelewing moet waarborg terwyl hy hindernisse vir die evangeliebediening op die openbare terrein uit die weg moet ruim" $(19$, p. 56$)$.

Dit is beslis buitensporing om te beweer dat die kerk op alle lewensterreine leiding moet gee. In die verband skryf Treurnicht soos volg: ,Indien die kerk behep raak met die gedagte dat hy oral leiding moet gee, sal hy meer as eens van homself 'n oorlas maak en dit sal sy eie skuld en verdiende loon wees indien sy leiding verontagsaam word" (19, p. 56). So, byvoorbeeld, neem die kerk nie leiding in sake soos die ekonomiese aspekte van die land, arbeidsmaatreëls, werkreservering, akkerbou, buitelandse handel, landsverdediging, die uitlê van woonbuurtes of wetgewing oor inkomstebelasting nie. Laasgenoemde lê op die terrein van die staatkundige en volkslewe. Op sodanige terreine kan die kerk hom net inlaat met 'n onbetwisbare beroep op Gods Woord (vgl. ook 1, pp. 345 - 353; 6, pp. 74 - 85, pp. 87 102 ; 8 , pp. $82-85$; 15 , p. 47 , p. $240 ; 19$, pp. $23-25$; 18, p. 19).

Aan die hand van die uiteensetting hierbo gegee, word vervolgens oorgegaan tot die jeug se siening van die verhouding tussen die kerk en die staat. In tabel 1 word die betrokke aspek volgens die huistaal van die jeugdiges ontleed.

Betragting van die gegewens in tabel 1 bring aan die lig dat bykans twee derdes van die jongmense (64.5\%) die Calvinistiese beskouing, naamlik dat die kerk die staat slegs moet aanspreek wanneer die staat — volgens die kerk se oordeel - die Wet van God oortree, ondersteun. Verder is 10.0 persent van die jeugdiges die mening toegedaan dat die kerk ondergeskik moet wees aan die staat, terwyl 9.1 persent wil dat die staat ondergeskik moet wees aan die kerk.

Laasgemelde uitgangspunt (die staat moet ondergeskik wees aan die kerk) is een wat algemeen onder die Roomse Kerk voorkom en die Caesero-papisme genoem word. Dit beteken dan dat die pous die oppergesag in die land moet besit (vgl. 19, pp. 132 133; 6, p. 81). Gesien in die lig van die Liberalisme se ontkenning van die eiesoortige en selfstandige struktuur en funksies van die onderlinge lewensverbande, bestaan die ruimte in 'n liberalistiese stelsel van oorheersing van die kerk deur die staat of andersom (vgl. 15, pp. $256-257$ ).

As die jeugdiges se opvatting oor die verhouding tussen kerk en staat volgens hulle huistaal ontleed word, blyk dat 'n groter persentasie Afrikaans- $(69.4 \%)$ as Engelssprekendes $(53.7 \%)$ die Calvinistiese beskouing tot dien effekte ondersteun. Dit is verder 


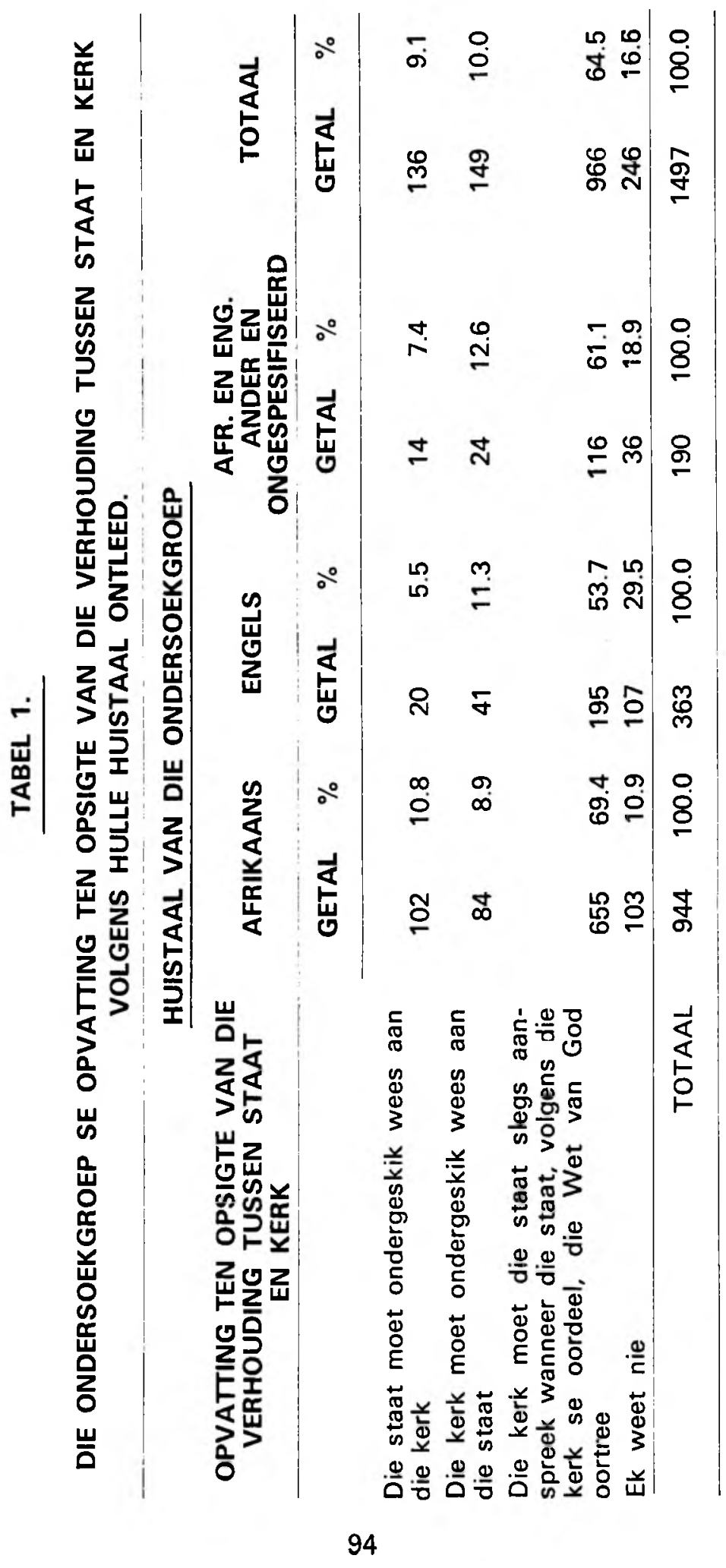


opmerklik dat proporsioneel baie meer Engels- $(29.5 \%)$ as Afrikaanssprekendes $(10.9 \%)$ nie weet watter standpunt om ten opsigte van die onderhawige aspek in te neem nie.

Vervolgens word die jongmense se opvatting oor die verhouding tussen die staat en die kerk in tabel 2 volgens hulle kerkverband ontleed (p. 9). As die gegewens in tabel 2 in o'enskou geneem word, kan die volgende algemene gevolgtrekkings gemaak word:

(a) Die uitgangspunt dat die kerk die staat moet aanspreek slegs wanneer laasgenoemde, volgens die kerk se oordeel, die Wet van God oortree, vind na verhouding sy grootste ondersteuning by die drie Afrikaanse Susterkerke, naamlik 70.0 persent van die N.G.-Kerk, 68.9 persent van die Hervormde Kerk en 76.1 persent van die Gereformeerde Kerk.

(b) Die Calvinistiese standpunt - soos in die reeds gemelde uitgangspunt weergegee - verkry proporsioneel die minste ondersteuning van die lidmate van die Joodse Kerk $(45.9 \%)$ en die Apostoliese Geloofsending (49.0\%).

Op grond van die bevindinge in die bepaalde verband, skyn dit gevolglik asof relatief meer jeugdiges van die drie Afrikaanse Susterkerke as ander, die Calvinistiese sienswyse van die verhouding tussen die kerk en die staat onderskraag.

\section{Die jeugdiges se beskouing van die Bybel}

Dit kan sonder vrees vir enige teenspraak gekonstateer word dat die ortodoks-tradisionele opvatting van die Bybel wat gangbaar is by die persoon wat ' $n$ Calvinistiese standpunt huldig en uitleef, die opvatting is dat die Bybel die geopenbaarde Woord van God is. Die Christengelowige glo dat die Bybel die Woord van God is, betroubaar en eg vanaf Genesis tot Openbaring. Neser beweer: „Die Bybel is die openbaring van die Wil en Plan van God" (10, p. 20). Stoker skryf in die verband soos volg: „Die ,formele' grondbeginsel van die Calvinistiese Reformasie is die goddelike onfeilbare gesag van die Heilige Skrif"' (15, p. 220). Wanneer hy oor die belydenis van die kerk skryf, maak Krüger onder meer die volgende stelling: „Hierdie Kerkleer (belydenis, dogma) stel homself nie naas of teenoor, maar wel onder en in ooreenstemming met die Bybel, as die alleen gesaghebbende outoriteit in sake van die christelike leer en lewenswandel" (6. p. 30).

Die Christen bely dat die Bybel as die Heilige Skrif van God, 


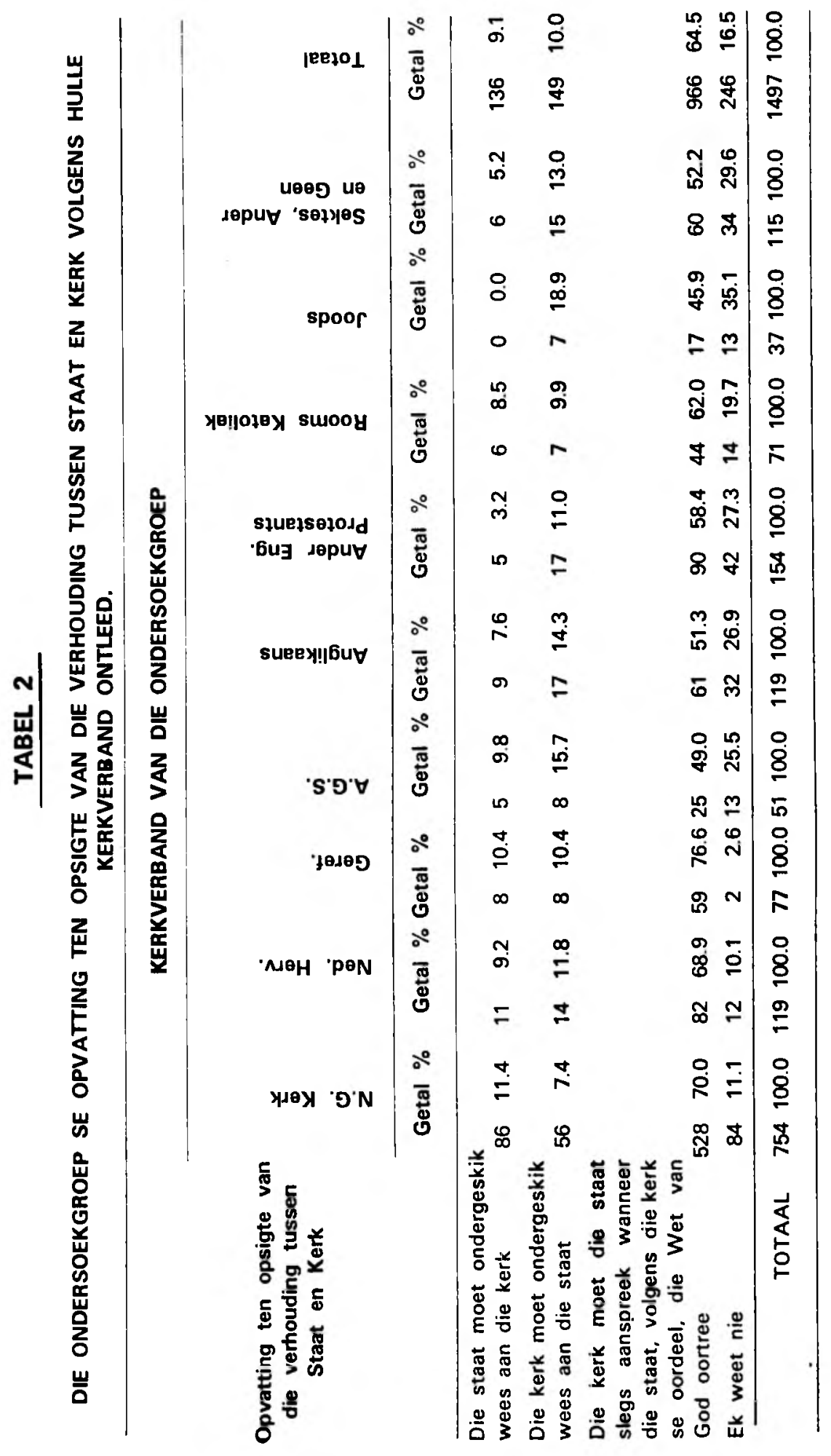


openbaar Wie God is, en wat Sy verhouding tot die skepping en veral die mens is. Voorts werp dit goddelike lig op die oorsprong. wese, aard en doel van die skepping, asook op die oorsprong, wese, aard en bestemming van die mens op aarde. Die Bybel het universele betekenis vir die mens en is in universele sin 'n lig op sy pad en 'n lamp vir sy voet.

Sonder om in enige teologiese diskussie betrokke te raak, kan die Calvinistiese opvatting van die Bybel soos volg in die woorde van Stoker saamgevat word: „Of die mens nou tot God bid en Hom loof in sy godsdiens, of hy sedelik handel, of hy die reg vorm, of hy kuns skep, of hy ekonomiese goedere produseer en verhandel, of hy wetenskap vorm, of hy taal vorm, of hy geskiedenis maak, of hy siekes genees, of hy diere dresseer, of hy die aarde bewerk, ploeg, saai en maai, of hy huise bou, of hy eet, of drink, wakker is of slaap, of hy werk of speel - op alles wat hy as individuele of as sosiale wese doen en laat, werp die Heilige Skrif sy lig en vir dit alles is hierdie Woord van God 'n rigsnoer vir sy lewe" (15, p. 221).

In die volgende twee tabelle word die jeug se beskouing van die Bybel volgens hulle huistaal en kerkverband ontleed. Tabel 3 laat die lig val op die jongmense se beskouing van die Bybel, volgens hulle huistaal ontleed.

\section{TABEL 3}

JEUGDIGES SE BESKOUING VAN DIE BYBEL VOLGENS HULLE HUISTAAL

TAAL

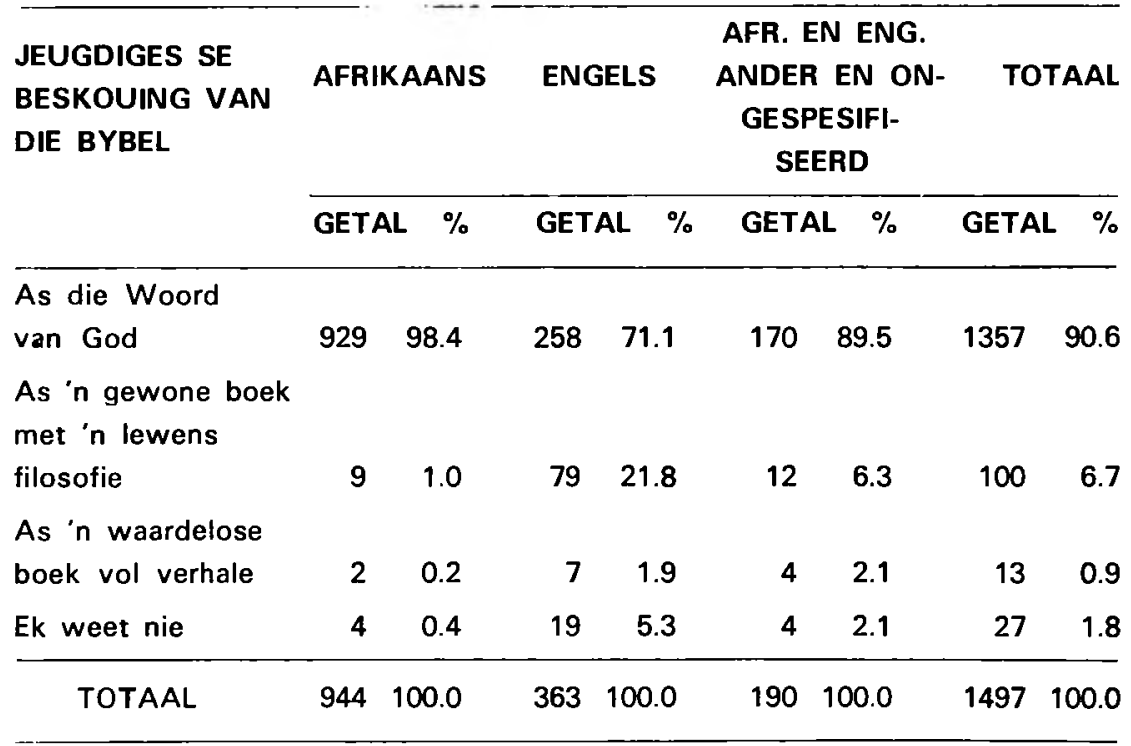


Dit blyk ondubbelsinnig uit die gegewens van die tabel onder bespreking dat die oorgrote meerderheid van die jeugdiges, naamlik 90.6 persent, die Bybel as die Woord van God beskou. Slegs 6.7 persent van die jongmense beskou dit as ' $n$ gewone boek met 'n lewensfilosofie, terwyl net 0.9 persent die Bybel as ' $n$ waardelose boek vol verhale bestempel.

Bogemelde bevindinge dui onomwonde op die hoë waarde wat die jeug aan die Christelike opvatting van die Bybel heg. Dit kan ook aanvaar word dat die Bybel, as synde een van die „sentrale simbole" van die godsdiens, 'n stabiliserende en bepalende rol in die lewe van die jeugdiges speel.

Enkele opmerkings dien gemaak te word aangaande die enkele jeugdiges wat die Bybel as 'n gewone boek vol verhale beskou. In die Russian Dictionary, volume 111, nommer 7, 27 Maart 1951 onder die opskrif Christian Economics, vind Skousen die volgende offisiële siening van die Kommunisme oor die Bybel: „A collection of fantastic legends without any scientific support. It is full of dark hints, historical mistakes and contradictions. It serves as a factor for gaining power and subjugating the unknowing nations" $(25$, p. 306). Dit lyk dus skynbaar asof diegene wat die Bybel as ' $n$ waardelose boek vol verhale beskou, grootliks met die kommunistiese standpunt in dier voege saamstem.

In 'n onderhoud met prof. dr. B. J. Engelbrecht, het hy aan skrywer meegedeel dat die persone wat die Bybel as ' $n$ gewone boek met 'n lewensfilosofie beskou waarskynlik die Humanisme aanhang. Vir hulle gaan dit om 'n lewensfilosofie en die lewe is vir hulle van groot belang. Dit maak nie saak waarin hierdie filosofie opgeteken staan nie (byvoorbeeld die geskrifte van Buddha). Die mense is waarskynlik ook modern, kultureel gevorm en ontwikkel, esteties sensitief en kan ook sekere waardes huldig. Sodanige waardes is egter nie fundamenteel religieus nie maar humanisties. Die persoon soek na 'n stel van waardes en norme, dog beweeg weg van die Bybel in sy soeke daarna. In hierdie opsig maak hy hom skuldig aan sekularisasie (vgl. 20, p. 11).

Tydens dieselfde onderhoud het prof. Engelbrecht opgemerk dat diegene wat die Bybel as ' $n$ waardelose boek vol verhale beskou, tiperend is van die moderne liberale opvatting van die godsdiens. Die persoon is liberaal omdat hy "gelibereer" gemaak is, losgemaak is van alle tradisionele waardes en opvattinge ook die oorgelewerde Bybelse waardes.

Wanneer die jeugdiges se beskouing van die Bybel volgens hulle huistaal ontleed word, val dit op dat ' $n$ groter persentasie Afrikaans $(98.4 \%)$ as Engelssprekendes $(71.1 \%)$, die Bybel as 
die Woord van God bestempel. Nog opmerkliker is die feit dat na verhouding baie meer Engelssprekendes (21.8\%) as Afrikaanssprekendes $(1.0 \%)$, die Bybel as 'n gewone boek met 'n lewensfilosofie beskou. Dit wil dus voorkom asof proporsioneel meer Afrikaanssprekende jeugdiges as Engelssprekende jongmense die Christelike opvatting met betrekking tot die Bybel onderskryf.

Voorts word die jeugdiges se beskouing van die Bybel in tabel 4 volgens hulle kerkverband ontleed. Die volgende bevindinge word deur die gegewens in hierdie tabel aan die lig gebring.

(a) Die meeste lidmate van al die onderskeie kerke verklaar dat hulle die Bybel as die Woord van God beskou. Na verhouding word die pas gemelde beskouing meer onder die lidmate van die drie Afrikaanse Susterkerke as onder die lede van die ander kerke aangetref. Diegene wat die onderhawige beskouing ondersteun, kom persentueel die minste onder die lede van die Joodse Kerk voor $(51.4 \%)$.

(b) Uit die gegewens in tabel 4 blyk voorts dat diegene wat die Bybel as 'n gewone boek met 'n lewensfilosofie beskou, na verhouding meer voorkom onder die lidmate van die Joodse Kerk $(37.8 \%)$ en die Anglikaanse Kerk $(27.7 \%)$.

Op grond van bogemelde bevinding will dit voorkom asof die tradisioneel Christelike beskouing van die Bybel proporsioneel meer deur die lidmate van die drie Afrikaanse Susterkerke as deur die lidmate van die ander kerke ondersteun word.

\section{Die jeugdiges se opvatting aangaande die prediking} in die kerk.

'n Geestesstroming wat tans ook sy kop in Suid-Afrika uitsteek. 'n stroming van links wat veral op die kerk en die prediking in die kerk gemik is, staan algemeen onder skrywers in die verband as die ..social gospel" bekend. Deur hierdie nuwe evangelie word die kruis-prediking van versoening deur die skulddekkende bloed van Christus verdring deur 'n sosiale prediking van gelykheid en broederskap, van vryheid en menslike waardigheid. Volgens hierdie linkse denkrigting moet die kerk 'n sosiale instituut word en Christus, die Verlosser van sonde, dood en duiwel, moet voorgestel word as 'n sosiale hervormer (5, p. 2).

Volgens die "social gospel" moet die Koninkryk van God ten volle in hierdie tyd op die wêreld ontplooi en gaandeweg in die maatskappy verwerklik word. Dit is die taak van die mens om mee te werk aan die verwerkliking van hierdie ryk deur hervorming 


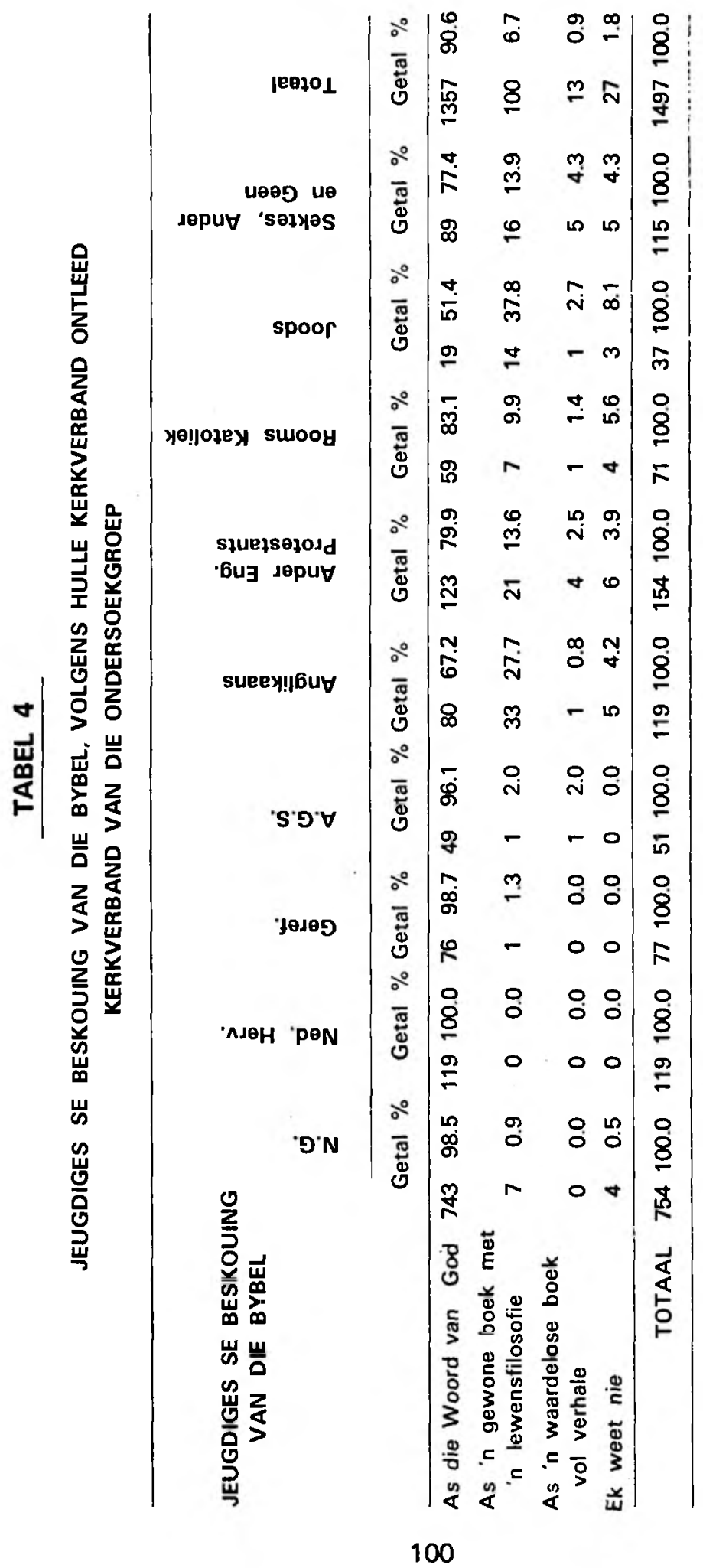


van die samelewing en deur ' $n$ beter samelewing tot stand te bring. In die verband konstateer Rauschenbusch soos volg:,, The Kingdom of God is still a collective conception, involving the whole social life of man. It is not a matter of saving human atoms, but of saving the social organism. It is not a matter of getting individuals to heaven, but of transforming the life on earth into the harmony of heaven" (13, p. 65).

Die „social gospel“ lê nadruk op die moralisme, die vermoë van die mens om self goed te wees en goed te doen. Dit gaan nie soseer om die bekeerde of wedergebore mens nie, maar die sosiale mens, die mens met sy aspirasies om hier op aarde self 'n beter en mooier wêreld te bou. Groot klem word gelê op die mens wat nie wil wag vir Gods verwerkliking van Sy Koninkryk in die nuwe hemel en die nuwe aarde nie, maar wat self die Ryk wil bou. Met betrekking tot die "social gospel” laat Pont hom soos volg uit: „Die Bybels-reformatoriese teologie waar Jesus Christus onbetwis in die sentrum staan, waar dit byna uitsluitlik gaan om God, die Here en sy groot dade, word deur die manne van die social gospel nog wel aanvaar maar dan alléén as 'n soort ,inleiding' tot die ware geloof en teologie want die geloof .... , word gerealiseer in die verhouding tot die naaste.' Die social gospel wil so min as moontlik te maak hê met die Drieenige God om so gou as maar moontlik is, te kom by sy eintlike doel en belangstelling: die mens en die moralisme".

Diegene wat die ,social gospel" bepleit, sien in die Koninkryk van God die volmaakte samelewing. Daarom moet onder meer maatskaplike en ekonomiese toestande op aarde sodanig verander dat die mens sonder kommer op aarde kan lewe. Hierdie hervorming van die samelewing is die beliggaming van Gods koningsheerskappy (16, p. 5).

In die hele proses word Jesus Christus nie gesien as die Lam van God wat die sonde van die wêreld wegneem nie, maar word $\mathrm{Hy}$ in die eerste plek voorgehou as ' $\mathrm{n}$ sosiale hervormer. Jesus Christus word dan bestempel as lemand wie se hoofdoel dit was om sosiale hervorming te predik en in te stel. In ' $n$ ander werk van Rauschenbusch, skryf hy in dié verband soos volg: "His (Christus) death was his greatest act of social service" (14, p. 68).

Uit bogemelde bondige uiteensetting behoort duidelik te blyk dat die eventuele oogmerke van die "social gospel" grootliks ooreenkom met die utopia of werkersparadys wat die Kommunisme aan sy volgelinge voorhou. Tereg beweer Pont dan ook dat die prediking van die „,social gospel“ beteken „vir ons tyd 
die propagering van die sosiaal-politieke program van die Kommunisme" (11, p. 7). Karl Marx rig hom tot sy volgelinge en doen 'n beroep op hulle om hom te volg ,and I will give you the one-world classless society, a paradise on earth which you can enjoy here and now. There is no God, no Jesus Christ or Saviour, no life after death. Follow me and I will give you the perfect world here and now" (23, p. 134).

In sy voortreflike referaat by die Volkskongres oor Kommunisme, wys Engelbrecht daarop dat die Kommunis fel teen die kerk te velde trek as laasgenoemde leer dat die Koninkryk van Christus nie van hierdie wêreld is nie, dat die Koninkryk van God nie spys en drank is nie, dat die Christen na die toekomstige dinge soek, dat Christene hulle burgerskap in die hemele het, .,dat vanuit ons onmag om ons te verlos en met die uitsig op die toekoms van die Here, alle aardse sake en verhoudinge heilsaam gerelativeer word en dat van hieruit die Christelike geloof en die Koninkryk van God nie sosiaal-politiek en militantrevolusionêr is nie, maar dat die Kerk die hemelse, ewige dinge moet preek en dan sal die Evangelie self soos 'n suurdeeg die sosiale verhoudinge geleidelik deursuur. . ..." (24, p. 37).

In dieselfde referaat dui Engelbrecht aan dat nêrens en nooit die Kommunisme só verdraagsaam teenoor die kerk is „as wanneer die kerk sy goddelike (hemelse) oorsprong vergeet en tot sosiale instituut word nie; as wanneer die kerk sy primêre bybelse, goddelike boodskap gaan vergeet en eensydig en primêr Social gospel gaan verkondig nie; as wanneer die kerk die toekomsverwagting links gaan laat lê en hier op aarde in hierdie bestel en geskiedenis 'n sigbare aardse koninkryk wil vestig nie. Dan het die Kommunisme die kerk en die evangelie waar hy hulle graag wil hê, naamlik hier op aarde (van die wêreld) en so 'n kerk en boodskap kan hy dan ook maklik beveg" $(24$, p. 38).

Implisiet wil die „social gospel” die kerk en die teologie moderniseer om aan te pas by die moderne sosiale omstandighede en die moderne wetenskap, kortom, by die „nuwe mens" wat maatstaf is van alle dinge en uiteindelik ook die gestalte, taak en boodskap van die kerk bepaal. Hierdie modernisering mak die weg oop vir die sosialisering van kerk en teologie. Eintlik gaan dit ook veel dieper. In die woorde van Engelbrecht: .Dit breek die gesag van Gods Woord (en ook van die kerk en predikers) af en daarmee van alle bestaande gesag, orde, moraliteit en ander waardes en waarhede. Sodoende word 'n vrugbare geestelike vakuum geskep vir die Kommunisme en sy sosiale boodskap" (24, p. 50; vgl. ook 7, p. 125; 9, p. 128; 11, p. 7, p. 20; 3, p. 9; 5, p. 2; 12, p. 13; 16, pp. 5, 7, 13, 17, pp. 9 e.v.). 


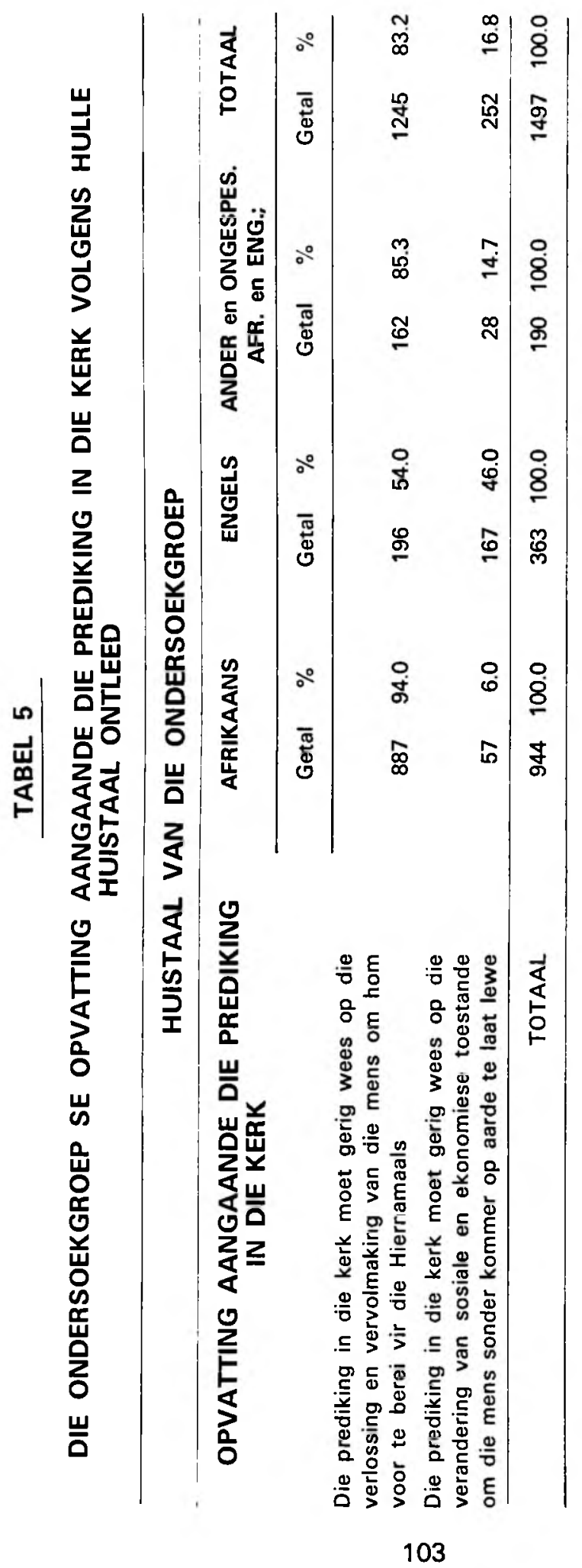


Vervolgens word die jeugdiges se mening rakende die prediking in die kerk in tabel $\mathbf{5}$ volgens hulle huistaal ontleed.

Blykens die gegewens in bogemelde tabel, verklaar die oorgrote meerderheid van die jeugdiges $(83.2 \%)$ dat die prediking in die kerk gerig moet wees op die verlossing en vervolmaking van die mens om hom voor te berei vir die Hiernamaals. Sestien punt agt (16.8) persent van die jeugdiges is van mening dat die prediking in die kerk gerig moet wees op die verandering van sosiale en ekonomiese toestande om die mens sonder kommer op aarde te laat lewe. Uit hierdie bevindinge spreek dit duidelik dat die oorgrote meerderheid van die jeugdiges en Suid-Afrika die leer wat die "social gospel" verkondig, verwerp.

As die opvatting van die jeugdiges ten opsigte van die pre. diking in die kerk volgens hulle huistaal ontleed word, tree die volgende bevindinge na vore:

(a) 'n Aansienlik groter persentasie Afrikaans- as Engelssprekende jeugdiges vereenselwig hulle met die werklike ortodokse Calvinistiese standpunt van die Afrikaanse kerk met betrekking tot die prediking. Dit blyk uit die feit dat 94.0 persent van die Afrikaans-, teenoor net 54.0 persent van die Engelssprekende jeugdiges, glo dat die prediking in die kerk gerig moet wees op die verlossing en vervolmaking van die mens om hom voor te berei vir die Hiernamaals.

(b) Hierteenoor blyk dat na verhouding baie meer Engels $(46.0 \%)$ as Afrikaanssprekendes $(6.0 \%)$ die prediking van die "social gospel” in die kerk voorstaan.

Die genoemde bevindinge regverdig die gevolgtrekking dat proporsioneel meer Afrikaans- as Engelsprekende jeugdiges die prediking van die „social gospel” om die Koninkryk van God op die aarde te vestig, verwerp.

In die hieropvolgende tabel (tabel 6) word die jeugdiges se opvatting ten opsigte van die prediking in die kerk volgens hulle kerkverband ontleed.

Blykens die gegewens in tabel 6 kan die volgende vernaamste gevolgtrekkings gemaak word:

(a) Die beskouing dat die prediking in die kerk gerig moet wees op die verlossing en vervolmaking van die mens om hom voor te berei vir die Hiernamaals, word na verhouding meer onder die N.G. Kerk $(94.8 \%)$, die Hervormde Kerk $(89.1 \%)$ en die Gereformeerde Kerk 


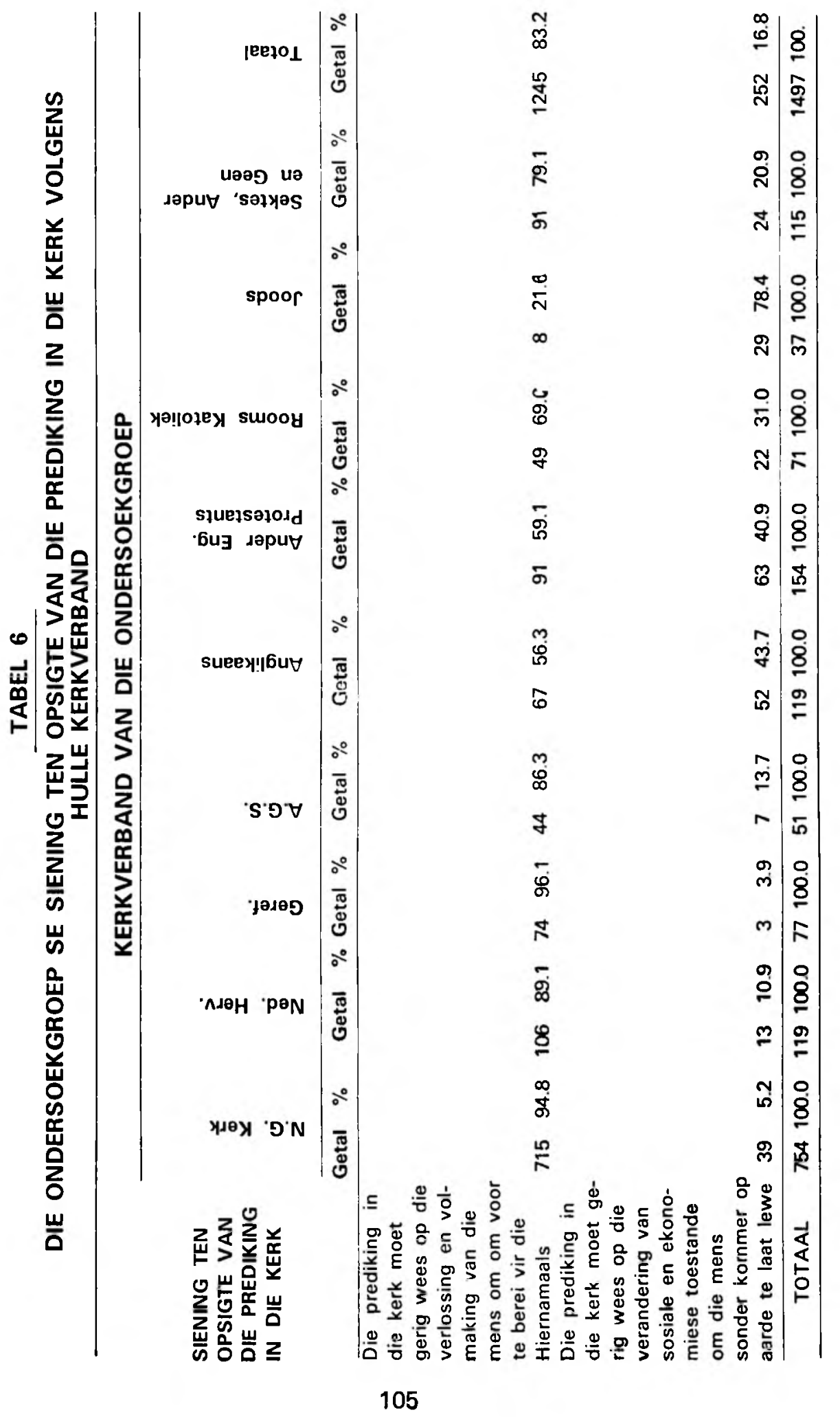


$(96.1 \%)$ as onder die ander kerke aangetref. Persentueel gesproke vind genoemde beskouing die minste ondersteuning van die Joodse Kerk $(21.6 \%)$ :

(b) Diegene wat die leer van die „social gospel” met betrekking tot die prediking in die kerk voorstaan, word na verhouding meestal onder die lidmate van die Joodse Kerk $(78.4 \%)$ en die Anglikaanse Kerk $(43.7 \%)$ aangetref.

Die verskynsel doen hom gevolglik voor dat na verhouding dit veral die lidmate van die drie Afrikaanse Susterskerke is wat die leerstelling van die "social gospel" in die kerk verwerp. Hierdie verskynsel hang waarskynlik nou saam met die feit dat die Afrikaanssprekendes gewoonlik die grootste persentasie lidmate van die drie Afrikaanse Susterskerke vorm.

\section{GEVOLGTREKKING.}

Met in agneming van die moontlike tekortkominge van die jeugondersoek, is die belangrikste gevolgtrekking waartoe waarskynlik geraak kan word dat die jeugdiges - met betrekking tot die aspekte wat hierbo bespreek is - oorwegend konserwatief on behoudend is ten opsigte van die ondersteuning en onderskryiving van dia Christelik-Calvinistiese lewens- en wêreldbeskouing. lierdie verskynsel is nie alleen bemoedigend nie, dog moet as 'n groot bate in die geestelike bcrusting van die jeug bestempel word.

Die tyd waarin die Republick se inworers hul vandag bevind, word onder andere gekenmerk deur aanslae wat op talryke wyses teen die land en sy mense geloods word. Van die belangrikste bedrciginge waaraan die Suid-Afrikaanse volk op die huidige tydstip blootgestel is, is die beinvloeding van sy lewensen wêreldbeskouing deur moderne geestestrominge of ideologië wat soos ' $n$ reuse golf oor die Suid-Afrikaanse bodem breek. Hierdie moderne strominge is ' $n$ wêreldverskynsel wat deur geen volk ter wêreld sonder meer geïgnoreer kan word nie. Derhalwe volg dit vanselfsprekend dat die volk van Suid-Afrika - en so ook die jeug van hierdie land - nie immuun kan staan teen beinvloeding van sodanige ideologië en strominge nie.

Waar sommige van die aanvalle veral toegespits word op die sedelik-godsdienstige terrein, is dit enigsins gerusstellend dat die jeugdiges so in positiewe beeld met betrekking tot die drie aspekte wat bespreek is, vertoon. Hopelik sal hierdie resultate, asook ander tendense wat deur die jeugondersoek blootgelê is, daartoe bydra om die negatiewe indruk wat deur baie mense aangaande die jeug gehandhaaf word, die nek in te slaan. 


\section{LITERATUURVERWYSINGS}

1. ALBERTYN, J. R. DU TOIT P. EN THERON, H.S.: Kerk en stad Pro Ecclesia Drukkery (Edms.) Bpk., Stellenbosch, 1947.

2. BUITENWEG, N. H.: Die "Social Gospel". Die Hervormer, Januarie 1965

3. BUITENWEG, N. H.: Nogmaals "Social Gospel". Die Hervormer, Augustus 1966.

4. DE WET, J. I.: "Social Gospel"? Nee! Die Hervormer, Julie 1965.

5. DREYER, JOH.: Die bakens na links. Die Hervormer, September 1964.

6. FEDERASIE VAN DIE CALVINISTIESE STUDENTEVERENIGINGS IN SUID-AFRIKA : Koers in die Krisis III. Pro Ecclesia Drukkery, Stellenbosch 1941.

7. GRESHAMMACHEN, J.: Christianity and Liberalism. Wm. B. Eerdmans Publishing Co., Grand Rapids, Michigan, 1923.

8. HANEKOM, T. N.: Kerk en Volk. Die verhouding tussen Afrikaanse lewenskringe. N. G. Kerk - Uitgewers, Ongedateerd.

9. HARGIS, B. J.: The Facts about Communism and our Churches. Christian Crusade, Box 977, Tulsa 2, Oklahoma, 1962.

10. NESER, F. W. C.: Apartheid. Wat sê die Skrif? Caxton, Pretoria, 1956.

11. PONT, A. D.: In Die Hervormer, Januarie 1965.

12. RAUSChenbuSCH, W.: Christianity and the Social Crisis. The Macmillan Company, Ltd., New York, 1912.

13. PONT, A. D.: Kroniek. Die Hervormer, Januarie 1964.

14. RAUSCHENBUSCH, W.: Christ.anizing the Social Order. The Macmillan Company, Ltd., New York, 1913.

15. STOKER, J. A.: Nabetragting. Die Hervormer, Januarie 1966, Februarie 1966, Maart 1966.

17. SWANEPOEL, J. A.: "Social Gospel" Die Hervormer, November 1964.

18. TREURNICHT, A. P.: Die Afrikaner en sy kerk. Die S.A.U.K.

19. TREURNICHT, A. P.: Op die Keper. Tafelberg Uitgewers, Kaapstad. 1965.

20. VAN ZYL, F. J.: Ons wêreld vandag. Die Hervormer, Maart 1967.

21. VENTER, E. A.: Die Gelowige in die Samelewing, Sacum Bpk., Bloemfontein, 1961.

22. VERITAS VINCENT, P. U. VIR C.H.O.: Republiek en Koninkryk. Pro Rege- Pers Beperk, Potchefstroom, 1964.

23. VERMAAK, C.: The Red Trap. Communism and Violence in South Africa. A. P. B. Publishers, Johannesburg, 1966.

24. VOLKSKONGRES OOR KOMMUNISME, DIE: Referate gelewer by die Volkskongres oor Kommunisme. 31 Maart - 2 April 1964.

25. SKONSEN, W. C.: The Naked Communist. The Ensign Publishing Company, Salt Lake City, Utah, 10e druk, 1961. 